\author{
Sustinere \\ Journal of Environment and Sustainability \\ Volume 5 Number 1 (2021) 1-8 \\ Print ISSN: 2549-1245 Online ISSN: 2549-1253 \\ Website: https://sustinerejes.com E-mail: sustinere.jes@iain-surakarta.ac.id
}

\title{
RESEARCH PAPER \\ Characterization of microcrystalline cellulose from fast-growing species Artocarpus elasticus
}

\author{
Sunardi ${ }^{1,4,}{ }^{*}$, W.T. Istikowati ${ }^{2,3}$, Norhidayah ${ }^{1}$, D. Ariyani ${ }^{1}$, and A. Kamari ${ }^{5}$ \\ ${ }^{1}$ Department of Chemistry, Mathematics and Natural Science Faculty, Lambung Mangkurat University, \\ Banjarbaru 70714, Indonesia \\ ${ }^{2}$ Forestry Faculty, Lambung Mangkurat University, Banjarbaru 70714, Indonesia \\ ${ }^{3}$ Forest Education and Research, Lambung Mangkurat University, Banjarbaru 70714, Indonesia \\ ${ }^{4}$ Wetland-Based Materials Research Center, Lambung Mangkurat University, Banjarbaru 70714, \\ Indonesia \\ ${ }^{5}$ Department of Chemistry, Faculty of Science and Mathematics, Universiti Pendidikan Sultan Idris, \\ 35900, Tanjong Malim, Perak, Malaysia \\ Article history: \\ Received 10 December 2021 | Accepted 16 April 2021 | Available online 30 April 2021
}

\begin{abstract}
Microcrystalline cellulose is an important derivative of cellulosic material obtained from wood and non-wood sources, and is used for pharmaceutical, food, cosmetics, and other industries. The aim of this study was to determine the effect of various hydrochloric acid concentrations on the characteristics of cellulose microcrystals isolated from terap wood (Artocarpus elasticus). The microcrystalline cellulose was hydrolyzed using hydrochloric acid, at concentrations of $1.5 \mathrm{~N}, 2.5 \mathrm{~N}$, and $3.5 \mathrm{~N}$ for 15 minutes, and within a temperature range of $100-105^{\circ} \mathrm{C}$. The samples were then analyzed for changes in color and functional groups with Fourier Transform Infrared spectroscopy (FTIR), while crystallinity index was evaluated through X-Ray Diffraction Analysis (XRD). The FTIR results showed similarity spectrum patterns between $\alpha$-cellulose and microcrystalline cellulose, while X-Ray Diffraction confirmed the highest crystallinity index was from $2.5 \mathrm{~N}$ of cellulose I (69.395 \%) and cellulose II (82.73 $\%)$.
\end{abstract}

Keywords: cellulose; microcrystalline cellulose; fast-growing species; crystallinity index; Artocarpus elasticus

\section{Introduction}

Cellulose is one of the biggest biopolymer in the world, with production rate of about 100 billion ton per year (Hermawan, 2017). In addition, there have been wide applications in various industries, as seen with food, paint, and biopolymers (Naduparambath \& Purushothaman, 2016). Cellulose can be hydrolyzed using acids to remove amorphous region and produce microcrystalline cellulose. Microcrystalline cellulose (MCC) is a white crystalline powder that is recognized as one of the widely used cellulose derivatives in cosmetics, food, pharmaceuticals, and filler industries. MCC is generally produced from cellulose by alkali treatment, although acid

${ }^{*}$ Corresponding author. E-mail: sunardi@ulm.ac.id ; masunardi@gmail.com DOI: https://doi.org/10.22515/sustinere.jes.v5i1.156 
hydrolysis method (Naduparambath \& Purushothaman, 2016; Trache et al., 2016) is faster than other methods. Several studies have reported the results of acid hydrolysis method, such as from bagasse (Zulharmita et al., 2017) and palm oil fiber (Xiang et al., 2016) produce high crystallinity of MCC. The solution used in this process is hydrochloride acid $(\mathrm{HCl})$, due to the low price and easy availability. The acid causes more reactive agent for removing amorphous part of cellulose compared to when $\mathrm{HNO}_{3}$ and $\mathrm{H}_{2} \mathrm{SO}_{4}$ are used (Nawangsari, 2019).

Although cotton is the main source for the commercial production of MCC, other sources such as sago seed sheel, palm oil fiber, and bagasse have also been reported to produce MCC. The properties of MCC depend not only on the acid type, but also on the source where it is extracted from. Terap wood (Artocarpus elasticus) is one of fast growing tree species that is naturally and abundantly distributed in the secondary forest of South Kalimantan, Indonesia (Istikowati et al., 2014). To date, research attention has been mainly focused on physical, mechanical and anatomical characteristics of terap wood (Artocarpus elasticus) as a wood and no investigation has been carried out on terap wood (Artocarpus elasticus) as a cellulose source for advanced applications. From the previous research, the wood contains $78.0 \%$ holocellulose, $50.7 \% \alpha$ cellulose, and 29.7\% lignin (Istikowati et al., 2016). The high cellulose content is a potential source for MCC production. Therefore, the main objective of this study is to evaluate the effect of $\mathrm{HCl}$ concentration on the properties of MCC produced through acid hydrolysis method.

\section{Material and Methods}

\subsection{Materials}

Terap wood (Artocarpus elasticus Reinw. ex Blume) were collected from secondary forest in the Education Forest at Lambung Mangkurat University, Mandiangin, South Kalimantan, Indonesia. Hydrochloric acid, acetic acid, ethanol, sodium hydroxide, sodium chlorite were obtained from E. Merck, German, and used without further modification.

\subsection{Methods}

Terap wood (trunk part) were dried for 3 days, mashed to powder 40-82 mesh size and then dried in the oven at $100-105^{\circ} \mathrm{C}$ until a constant weight was obtained. Holocellulose and $\alpha$-cellulose components were isolated based on the ASTM D1107-96 and the ASTM D 1103-60 standards, respectively. MCC was obtained from the latter. A total of 0.5 grams $\alpha$-cellulose was hydrolyzed using $\mathrm{HCl} 1.5 ; 2.5$; and $3.5 \mathrm{~N}(12 \mathrm{~mL})$ in beaker glasses, within a period of 15 minutes. After that, $25 \mathrm{~mL}$ of cold water was added and stirred vigorously to stop the hydrolysis process, and then reserved for 1 night. The MCC obtained were then filtered, washed with distillated water to attain a neutral $\mathrm{pH}$, and subsequently dried in the oven at $60^{\circ} \mathrm{C}$ for 30 minutes.

\subsection{Characterization}

The MCC obtained was analyzed using colorimeter, Fourier Transform Infrared (FTIR), and X-Ray Diffraction Analysis (XRD). A total of $100 \mathrm{mg}$ MCC was analyzed using colorimeter and the result was compared to the Avicel PH 102 standard, while the color was compared with the Ditjen POM 1979 standard. In addition, the sample pellet (2-5 mg) was combined with $\mathrm{KBr}$ (200-250 mg) and was measured with FTIR in the region of 4000-400 $\mathrm{cm}^{-1}$ wave numbers. The infrared spectra was used for estimation of the Total Crystallinity Index (TCI) (Nelson \& O'Connor, 1964). MCC was also mashed into powder and was analyzed with XRD to determine the crystallinity index (Crl) from cellulose, based on the Segal formula (Segal et al., 1959). 


\section{Results and Discussion}

\subsection{Holocellulose and $\alpha$-Cellulose Isolation}

Terap (Artocarpus elasticus) is one of unutilized native tree species from South Kalimantan. The species is naturally distributed and found abundantly in the secondary forest in South Kalimantan, Indonesia (Istikowati et al. 2014). Fig. 1 shows the photograph of terap (Artocarpus elasticus) tree species.

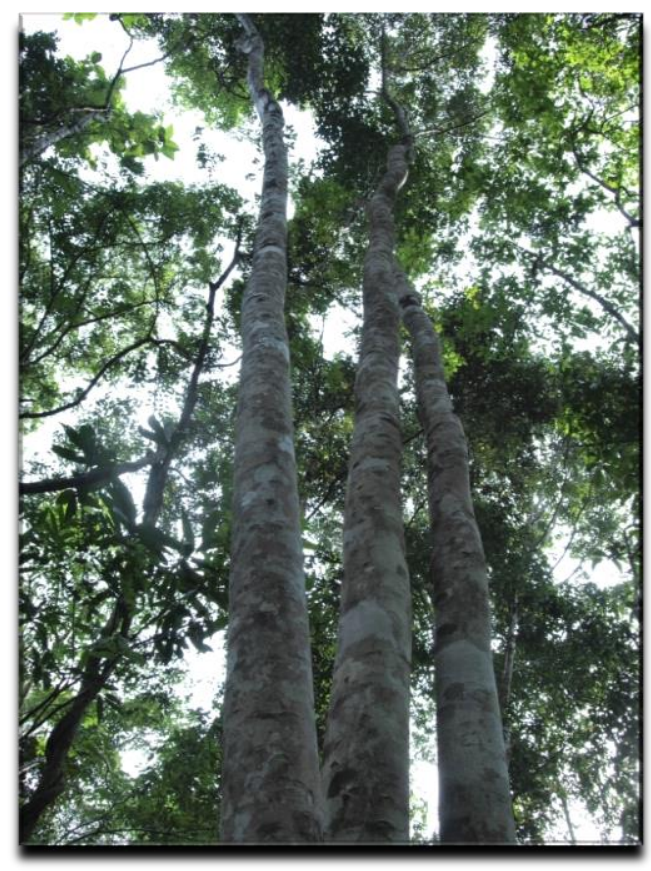

Figure 1. Photograph of terap tree (Artocarpus elasticus)

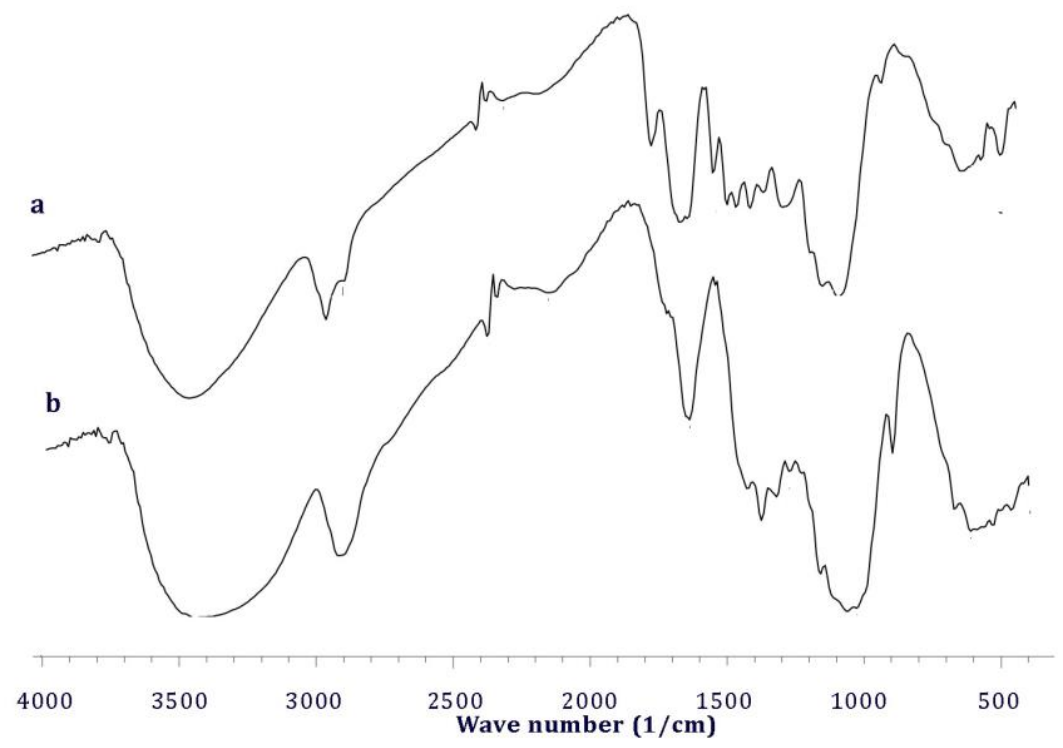

Figure 2. FTIR spectrum of (a) holocellulose and (b) $\alpha$-cellulose of terap wood (Artocarpus elasticus) 
Holocellulose and $\alpha$-cellulose of terap wood (Artocarpus elasticus) were analyzed with FTIR to determine the functional group present (Fig. 2), and different absorption patterns were observed in wave number with a shift because the absence of hemicellulose. For example, the area of 3400-2900 $\mathrm{cm}^{-1}$ is typical for stretching $\mathrm{O}-\mathrm{H}$ group and $\mathrm{C}-\mathrm{H}$. Table 1 shows the holocellulose absorption at a wave number of $1512.19 \mathrm{~cm}^{-1}$, which features the stretching vibration of $\mathrm{C}=\mathrm{C}$, indicating lignin compounds. In addition, wave number vibration $1735.93 \mathrm{~cm}^{-1}$ also appeared because of the amorphous parts (Sunardi et al., 2018).

Table 1. Holocellulose dan $\alpha$-cellulose specific peaks of FTIR of terap wood (Artocarpus elasticus)

\begin{tabular}{ccl}
\hline \multicolumn{2}{c}{ Wave number $\left(\mathbf{c m}^{-1}\right)$} & \multicolumn{1}{c}{ Functional group } \\
\cline { 1 - 2 } Holocellulose & $\boldsymbol{\alpha}$-cellulose & \multicolumn{1}{c}{ stretching O-H } \\
\cline { 1 - 2 } 2425.58 & 3448.72 & \\
& 3410.15 & stretching C-H \\
1735.93 & 2916.37 & hemicellulose stretching C-H \\
1635.64 & - & Water absorption O-H bonding \\
1512.19 & 1635.64 & C=C in lignin \\
1373.32 & - & -O-in cellulose \\
1327.03 & 1373.321319 .31 & \\
894.97, & 894.97 & C-O stretching glycoside bonds \\
1064.77 & 1064.71 & \\
1033.85 & & \\
\hline
\end{tabular}

\subsection{Isolation}

The percentage of MCC obtained from $\mathrm{HCl}$ hydrolysis of $1.5 \mathrm{~N}, 2.5 \mathrm{~N}$, and $3.5 \mathrm{~N}$ was $71.05 \%$, $57.64 \%$, and 53.23\%, respectively (Fig. 3). Based on Tukey test, significant differences were recognized at the three different formulations. According to Sumiati (Sumiati et al., 2016), higher $\mathrm{HCl}$ concentration in the hydrolysis process will remove not only amorphous phase, but also crystalline part of cellulose. This result also similar with the result from previous research (Sunardi et al., 2019). Also, there is an increase in glucose monomer formation, leading to improved dissolution in the washing process.

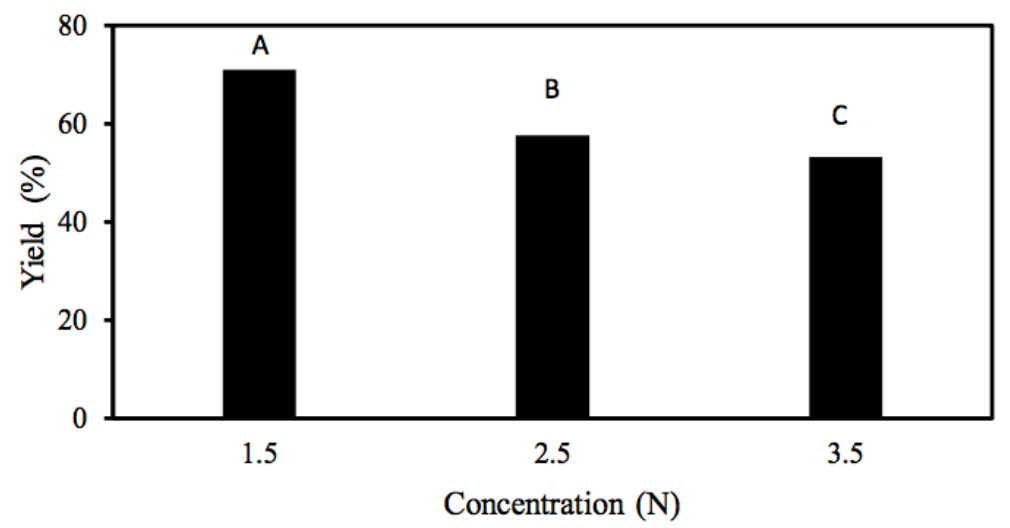

Figure 3. MCC yield in various concentration of $\mathrm{HCl}$ (A) $1.5 \mathrm{~N}$; (B) $2.5 \mathrm{~N}$; (C) $3.5 \mathrm{~N}$ ) 


\subsection{Characteristic of MCC}

\subsubsection{MCC color analysis}

Table 2 shows that the color of MCC in $1.5 \mathrm{~N} \mathrm{HCl}$ concentration has $\mathrm{L}^{*}$ value which is similar with $\mathrm{L}^{*}$ standard (87.01). Meanwhile the value of $\mathrm{a}^{*}, \mathrm{~b}^{*}$, and $\Delta \mathrm{E}$ increased with the increase of acid concentration. In addition, the indicators used to determine good MCC color was $\mathrm{L}^{*}$ value or the brightness level, and significant differences were reported between each group in this study.

Table 2. MCC colour of terap wood (Artocarpus elasticus)

\begin{tabular}{cccccc}
\hline No & HCl Concentration & $\mathbf{L}^{*}$ & $\mathbf{a}^{*}$ & $\mathbf{b}^{*}$ & $\mathbf{\Delta E}$ \\
\hline 1 & Standard (white paper) & 88.51 & 1.94 & 3.60 & \\
2 & $1.5 \mathrm{~N}$ & 87.01 & 5.16 & 16.24 & 4.76 \\
3 & $2.5 \mathrm{~N}$ & 82.15 & 6.66 & 16.58 & 15.66 \\
4 & $3.5 \mathrm{~N}$ & 80.83 & 6.76 & 17.39 & 16.95 \\
\hline
\end{tabular}

\subsubsection{Fourier Transform Infrared Spectroscopy Analysis of MCC}

The infrared spectrum of $\alpha$-cellulose and MCC obtained from terap wood (Artocarpus elasticus) in this study are shown in Fig. 3. The aim of the infrared spectroscopy analysis was to determine the functional groups of the $\alpha$-cellulose and MCC as a $\alpha$-cellulose derived. FTIR spectroscopy results of the $\alpha$-cellulose and MCC with various $\mathrm{HCl}$ concentrations shows similarity in the main absorption pattern functional group area. This was indicated by a shift in the number and transmittance value of $\mathrm{O}-\mathrm{H}$ stretching group, observed to be lower at $1.5 \mathrm{~N}$ and $2.5 \mathrm{~N}$, followed by a subsequent increase at $3.5 \mathrm{~N} \mathrm{HCl}$ (Fig. 4).

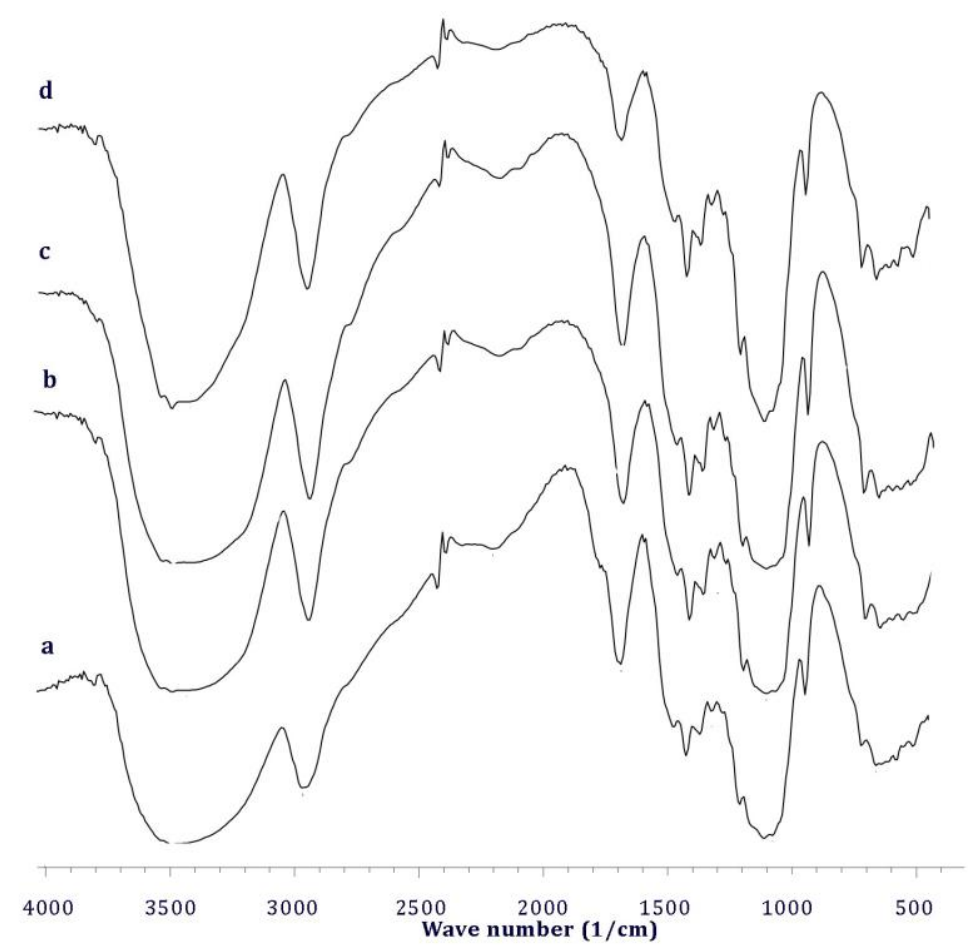

Figure 4. FTIR spectrum of cellulose and MCC obtained from terap wood (Artocarpus elasticus) with various $\mathrm{HCl}$ concentration (a) $\alpha$-cellulose; (b) $1.5 \mathrm{~N}$; (c) $2.5 \mathrm{~N}$; (d) $3.5 \mathrm{~N}$ 
The wave number pattern of $\alpha$-cellulose and MCC has similarities with commercial cellulose at 894.97, 1035-1060 $\mathrm{cm}^{-1}$ indicating the presence of C-O-C stretching (glycosidic bond). Also, the region of $1374 \mathrm{~cm}^{-1}$ and $1373 \mathrm{~cm}^{-1}$ shows the presence if -0- group in cellulose (Naduparambath \& Purushothaman, 2016). The $\mathrm{O}-\mathrm{H}$ and $\mathrm{C}-\mathrm{H}$ stretching on $\alpha$-cellulose and MCC treated with different $\mathrm{HCl}$ concentrations denote a shift in wave number because of hydrolysis process.

The 0 - $\mathrm{H}$ stretching groups of $\alpha$-cellulose identified in this study are formed at wave numbers of 3448.72 and 3410.15 , while C-H was at $2916.37 \mathrm{~cm}^{-1}$. Furthermore, MCC treated with $1.5 \mathrm{~N}$ HCL showed $\mathrm{O}-\mathrm{H}$ at 3441.01 and $3371.57 \mathrm{~cm}^{-1}$, while $\mathrm{C}-\mathrm{H}$ was at $2900.94 \mathrm{~cm}^{-1}$. The samples with $2.5 \mathrm{~N}$ treatment exhibited stretching $\mathrm{O}-\mathrm{H}$ groups at 3441.01 and $3363.86 \mathrm{~cm}^{-1}$, while $\mathrm{C}-\mathrm{H}$ was at 2893.22 $\mathrm{cm}^{-1}$. In addition, MCC with $3.5 \mathrm{~N} \mathrm{HCl}$ showed $\mathrm{O}-\mathrm{H}$ groups at 3441.01 and $3387.00 \mathrm{~cm}^{-1}$, while $\mathrm{C}-\mathrm{H}$ was $2893.22 \mathrm{~cm}^{-1}$.

The FTIR peak in MCC with wave number of $3441.01-3387 \mathrm{~cm}^{-1}$ indicates a decline in $\mathrm{O}-\mathrm{H}$ stretching group, while the absorption pattern widens, using the 1.5 and $2.5 \mathrm{~N} \mathrm{HCl}$ treatments. In addition, lower peak pattern cause an increase in the functional group absorbance, thus indicating the existence of intermolecular hydrogen bonds in the cellulose molecule.

Nelson and O'Connor method was used to determine the Total Crystallinity Index (TCI). This refers to the ratio of absorbance in wave number of $1373-1375 \mathrm{~cm}^{-1}$ indicating -0- functional group, and also 2800-2900 $\mathrm{cm}^{-1}$ for $\mathrm{C}-\mathrm{H}$ and $\mathrm{CH}_{2}\left(\mathrm{~A}_{1373} / \mathrm{A}_{2800}\right)$ stretching (Nelson \& O'Connor, 1964; Sunardi et al., 2018). Table 3 shows the TCI value of MCC.

Table 3. TCI MCC of terap (A. elasticus) wood

\begin{tabular}{cc}
\hline HCl Concentration (N) & TCI \\
\hline 1.5 & 0.992 \\
2.5 & 0.993 \\
3.5 & 0.963 \\
\hline
\end{tabular}

The Total Crystallinity Index (TCI) estimates the influence of varied $\mathrm{HCl}$ concentrations, which increased from 1.5 to $2.5 \mathrm{~N}$, followed by a decline at 3.5. The data obtained showed that the treatment with $2.5 \mathrm{~N}$ gave the highest $\mathrm{TCl}$ value. Thus, the treatment is concluded as the optimum parameter for hydrolysis, due to the adequate loss of amorphous cellulose (Klemm et al., 1998).

\subsubsection{X-Ray Diffraction Analysis}

Fig 5 shows the XRD analysis of MCC, and there are similarities in the patterns obtained from three different $\mathrm{HCl}$ concentrations. In addition, all samples showed two diffractogram peaks in the crystalline area in the (002) and (200) Miller index with an angle of $(2 \theta)=21-22^{\circ}$. These indicate the presence of two types of crystal cellulose, interpreted as cellulose I and II (Klemm et al., 1998; Xiang et al., 2016). Moreover, treatment with $1.5 \mathrm{~N} \mathrm{HCl}$ shows the crystallinity index of cellulose I and II at ( $2 \theta$ ) angle $=21.95^{\circ}$ and $20.05^{\circ}$ with intensity value of 549 and 596 , while the amorphous area appears at $(2 \theta)$ angle $12.15^{\circ}$ and $14.05^{\circ}$, with 170 and 119 intensity. Hence, the crystallinity indexes were computed as $69.03 \%$ and $80.03 \%$, respectively. Conversely, $69.39 \%$ and $82.73 \%$ was recorded for MCC with $2.5 \mathrm{~N}$ treatment, which appeared at $(2 \theta)$ angle $=21.895^{\circ}$ and $20.03^{\circ}$ with intensity value 549 and 608 , while the amorphous area was at $(2 \theta)$ angle $=12.26^{\circ}$ and $14.05^{\circ}$ with intensity of 168 and 105. In addition, the crystallinity index of $67.25 \%$ and $75.86 \%$ were

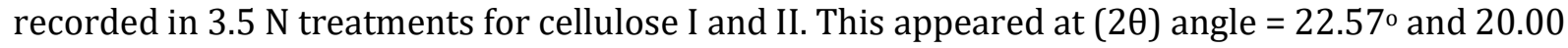




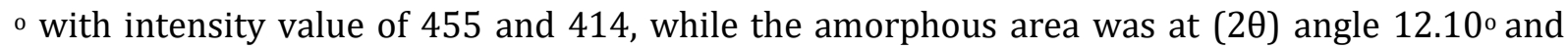
$14.05^{\circ}$ with intensity of 149 and 100 , respectively.

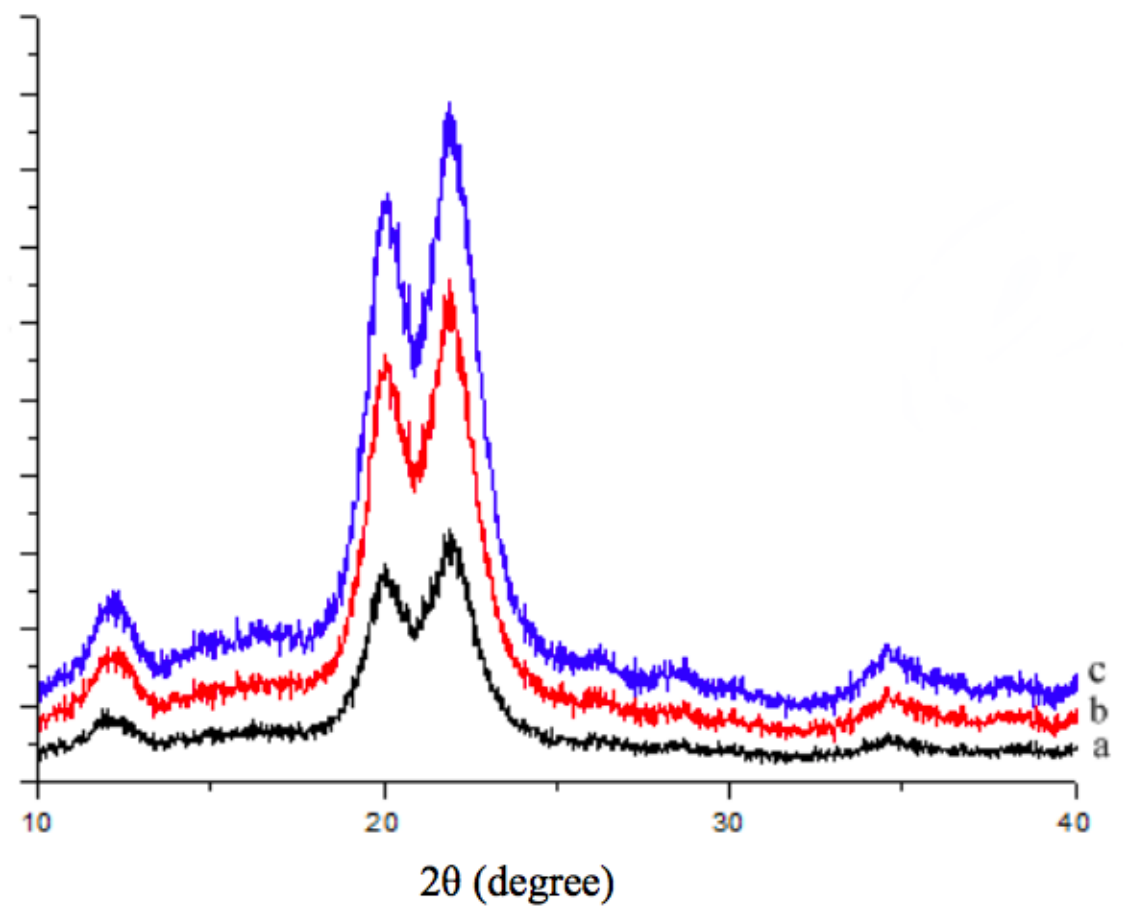

Figure 5. Diffractogram of MCC from terap (A. elasticus) wood in various $\mathrm{HCl}$ concentration (a) $1.5 \mathrm{~N}$; (b) $2.5 \mathrm{~N}$; and (c) $3.5 \mathrm{~N}$

Table 4 shows the CrI of MCC where it can be seen that the value of cellulose II is higher than the value of cellulose I due to the relatively better stability. Furthermore, the CrI was reported to have increased from $\mathrm{HCl}$ concentration of $1.5 \mathrm{~N}$ to $2.5 \mathrm{~N}$, followed by a decline at $3.5 \mathrm{~N}$. This phenomenon occurs due to the cutting speed of amorphous areas in cellulose during hydrolysis (Steven et al., 2014). Based on the characterization result, $2.5 \mathrm{~N}$ was confirmed to be the optimum $\mathrm{HCl}$ concentration needed to isolate MCC from terap wood.

Table 4. Crystallinity index of MCC obtained from terap wood (Artocarpus elasticus)

\begin{tabular}{cccc}
\hline No & HCl concentration (N) & $\begin{array}{c}\text { Crystallinity index } \\
\text { cellulose I (\%) }\end{array}$ & $\begin{array}{c}\text { Crystallinity index } \\
\text { cellulose II (\%) }\end{array}$ \\
\hline 1 & 1.5 & 69.03 & 80.03 \\
2 & 2.5 & 69.39 & 82.73 \\
3 & 3.5 & 67.25 & 75.86 \\
\hline
\end{tabular}

\section{Conclusion}

FTIR analysis shows the similarity peak patterns between $\alpha$-cellulose and MCC from terap wood. In addition, XRD identified the highest crystallinity index in cellulose I (69.395 \%) and cellulose II (82.73\%), using $2.5 \mathrm{~N} \mathrm{HCl}$. This is further recommended as the optimum acid concentration to isolate MCC from terap wood through the hydrolysis process. 


\section{Acknowledgement}

The authors express their thank to Biomaterials Chemistry Laboratory, Chemistry Department, Faculty of Mathematics and Natural Sciences, Lambung Mangkurat University for the facilities.

\section{References}

Hermawan, E. (2017). Pembuatan Partikel Selulosa Menggunakan Larutan Alkalin. Jurnal Teknik Mesin, 6(1), 56. doi:10.22441/jtm.v6i1.1337

Istikowati, W. T., Aiso, H., Sunardi, Sutiya, B., Ishiguri, F., Ohshima, J., Iizuka, K., \& Yokota, S. (2016). Wood, Chemical, and Pulp Properties of Woods from Less-Utilized Fast-Growing Tree Species Found in Naturally Regenerated Secondary Forest in South Kalimantan, Indonesia. Journal of Wood Chemistry and Technology, 36(4), 250-258. doi:10.1080/02773813.2015.1124121

Istikowati, W. T., Ishiguri, F., Aiso, H., Hidayati, F., Tanabe, J., Iizuka, K., Sutiya, B., Wahyudi, I., \& Yokota, S. (2014). Physical and Mechanical Properties of Woods from Three Native Fast-Growing Species in a Secondary Forest in South Kalimantan, Indonesia. Forest Products Journal, 64(1-2), 48-54. doi:10.13073/fpj-d-13-00069

Klemm, D., Philipp, B., Heinze, T., Heinze, U., \& Wagenknecht, W. (1998). Comprehensive Cellulose Chemistry: Wiley.

Naduparambath, S., \& Purushothaman, E. (2016). Sago Seed Shell: Determination of the Composition and Isolation of Microcrystalline Cellulose (Mcc). Cellulose, 23(3), 1803-1812.

Nawangsari, D. (2019). Isolasi Dan Karakterisasi Selulosa Mikrokristal Dari Ampas Tebu (Saccharum Officinarum L.). Pharmacon: Jurnal Farmasi Indonesia, 16(2), 67-72. doi:10.23917/pharmacon.v16i2.9150

Nelson, M. L., \& O'Connor, R. T. (1964). Relation of Certain Infrared Bands to Cellulose Crystallinity and Crystal Latticed Type. Part I. Spectra of Lattice Types I, Ii, Iii and of Amorphous Cellulose. Journal of Applied Polymer Science, 8(3), 1311-1324. doi:10.1002/app.1964.070080322

Segal, L., Creely, J. J., Martin, A. E., \& Conrad, C. M. (1959). An Empirical Method for Estimating the Degree of Crystallinity of Native Cellulose Using the X-Ray Diffractometer. Textile Research Journal, 29(10), 786794. doi:10.1177/004051755902901003

Steven, Mardiyati, \& Suratman, R. (2014). Pembuatan Mikrokristalin Selulosa Rotan Manau (Calamus Manan Sp.) Serta Karakterisasinya. JURNAL SELULOSA, 4(02). doi:10.25269/jsel.v4i02.84

Sumiati, M., Wahyuni, D., \& Baraâ, M. (2016). Analisis Hubungan Konsentrasi Asam Saat Hidrolisis, Derajat Kristalinitas Dan Sifat Mekanis Selulosa Kristalin Dari Serbuk Gergaji Kayu. PRISMA FISIKA, 4(2), 6468.

Sunardi, Istikowati, W. T., \& Sari, D. I. (2019). Extraction of A-Cellulose from Eleocharis Dulcis Holocellulose Using Naoh and Koh. Journal of Physics: Conference Series, 1397, 012031. doi:10.1088/1742$6596 / 1397 / 1 / 012031$

Sunardi, S., Istikowati, W. T., Ishiguri, F., \& Yokota, S. (2018). Ftir Spectroscopy and Color Change of Wood for Assessment and Monitoring of Softwood Degradation by White-Rot Fungus Porodaedalea Pini. http://dx.doi.org/10.1063/1.5064984

Trache, D., Hussin, M. H., Hui Chuin, C. T., Sabar, S., Fazita, M. R. N., Taiwo, O. F. A., Hassan, T. M., \& Haafiz, M. K. M. (2016). Microcrystalline Cellulose: Isolation, Characterization and Bio-Composites Applicationa Review. International Journal of Biological Macromolecules, 93, 789-804. doi:10.1016/j.ijbiomac.2016.09.056

Xiang, L. Y., P. Mohammed, M. A., \& Samsu Baharuddin, A. (2016). Characterisation of Microcrystalline Cellulose from Oil Palm Fibres for Food Applications. Carbohydrate Polymers, 148, 11-20. doi:10.1016/j.carbpol.2016.04.055

Zulharmita, Z., Dewi, S., \& Mahyuddin, M. (2017). Pembuatan Mikrokristalin Selulosa Dari Ampas Tebu (Saccharum Officinarum L.). Jurnal Sains dan Teknologi Farmasi, 17, 158-163. 